\title{
Article
}

\section{The Use and Abuse of Special-Purpose Entities in Public Finance}

\section{Steven L. Schwarcz ${ }^{\dagger}$}

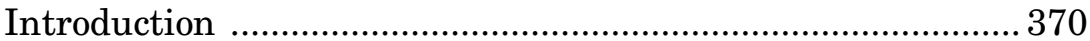

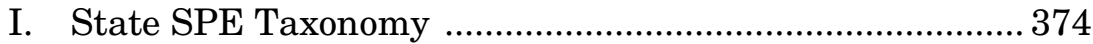

A. Engaging in Interstate Functions .............................. 374

B. Running State Programs as Enterprises ..................... 375

C. Avoiding Constitutional Debt Limits .......................... 375

D. Financing Private Projects .......................................... 376

E. Reducing State Financial Transparency .................... 376

II. Potential Illegitimacies .................................................... 377

A. Constitutional Illegitimacy and Tax Avoidance .......... 378

B. Reducing Transparency and Avoiding Public

Scrutiny ...................................................................... 378

1. De Facto "Guarantees" ......................................... 381

2. Consequences of Lack of Transparency ................. 383

3. Comparing State and Corporate SPE Lack of Transparency

4. Undermining Democratic Control of State

Functions

III. Towards Regulatory Solutions ....................................... 389

A. Recent State SPE Reform Efforts .............................. 390

B. Recent Corporate SPE Reform Efforts ....................... 391

C. A Broader Conceptual Framework for Reform ............ 393

D. Applying the Framework …......................................... 395

1. Improving Transparency of State SPE Debt ........ 396

2. Improving Monitoring of State SPE Debt ............ 397

3. Limiting State SPE Debt ..................................... 398

$\dagger \quad$ Stanley A. Star Professor of Law \& Business, Duke University School of Law, and Founding Director, Duke Global Capital Markets Center; schwarcz@law.duke.edu. I thank Lawrence G. Baxter, Cheryl D. Block, Scott Fein, Jonathan D. Rosenbloom, Richard C. Schragger, George Weissman, and participants in a faculty workshop at Duke University School of Law for valuable comments and Justin Chivinski, Gregory McKay, and Lucy Chang for invaluable research assistance. Copyright (C) 2012 by Steven L. Schwarcz. 


\section{INTRODUCTION}

States increasingly are raising financing indirectly through special-purpose entities (SPEs), variously referred to as authorities, special authorities, or public authorities. ${ }^{1}$ Some states, such as New York, New Jersey, and Virginia, issue relatively few general obligation bonds, ${ }^{2}$ obtaining most of their financing through bonds issued by state SPEs:

[A] state such as New York, for example, with one of the highest percapita debt burdens in the nation, owes only $\$ 3.5$ billion in "general obligation" debt. New York owes the remainder of its $\$ 78.4$ billion in debt through hundreds of special "authorities," including the Transitional Finance Authority, Metropolitan Transportation Authority, the Dormitory Authority, and others.

Virtually all states obtain at least a portion of their public financing through state SPEs. ${ }^{4}$

1. See, e.g., Lynn Wilson \& Clayton Eichelberger, New York State Public Authority Reform: Where We Have Come from and Where We Need to Go, GOV'T L. \& POL'Y J., Fall 2009, at 15, 15. Perhaps the nation's most wellknown example of a state SPE is the Port Authority of New York and New Jersey, whose operations include the tunnels and bridges between New York and New Jersey, the PATH rail system, and the JFK, LaGuardia, and Newark airports. See infra note 20 and accompanying text.

2. These are the traditional debt securities issued by states, payment of which is backed directly by a state's full faith and credit and taxing power. General Obligation Bond (G.O. Bond), Mun. SeCS. Rulemaking BoARD, http://www.msrb.org/msrb1/glossary/view_def.asp?param=

GENERALOBLIGATIONBOND (last visited Oct. 27, 2012).

3. Nicole Gelinas, "State and Municipal Debt: The Coming Crisis?", PuB. SECTOR INC. (Feb. 7, 2011, 8:43 AM), http://www.publicsectorinc.com/psi_ articles/2011/02/state-and-municipal-debt-the-coming-crisis.html; see also Claire G. Cohen, Fitch Ratings, State DebT and Exposure to DebT-LiKe COMMITMENTS 2 (2006) (observing that "New York, New Jersey, and Virginia finance almost exclusively through authorities").

4. Rhonda Riherd Trautman, The Impact of State Debt Management on Debt Activity, Pub. Budgeting \& Fin., Summer 1995, at 33, 35 tbl.1, 38 tbl.2; see also JERRY MITCHELL, THE AMERICAN EXPERIMENT WITH GOVERNMENT CORPORATIONS 15 (1999) ("At the subnational level, government corporations can be found in every state and most localities."); Gail Radford, From Municipal Socialism to Public Authorities: Institutional Factors in the Shaping of American Public Enterprise, 90 J. AM. HIST. 863, 867 (2003) (“All Americans now live within overlapping layers of quasi-governmental units responsible for public services ....”). 
Notwithstanding their long history and increasingly widespread use, relatively little is known about state SPEs. ${ }^{5}$ Originally modeled on the Port Authority of London, ${ }^{6}$ state SPEs were first used in the United States in the late nineteenth century. ${ }^{7}$ They initially were seen as a way to bypass various restrictions that hampered traditional government agencies, notably constitutional debt limits and jurisdictional limitations. ${ }^{8}$ In recent years, however, the use of state SPEs increasingly has been paralleling the use of special-purpose entities in corporate finance (hereinafter, corporate SPEs) as a means of raising "off-balance-sheet" financing. ${ }^{9}$ This is a financing in which

5. Jonathan Rosenbloom, Can a Private Corporate Analysis of Public Authority Administration Lead to Democracy?, 50 N.Y.L. SCH. L. REV. 851, 870 (2005-2006) ("Despite an increase in the number of public authorities, the services they render and the debt they issue, public authorities remain a fairly unstudied matter."). The scholarship on state SPEs is not only sparse but also decades old. See, e.g., William T. R. Fox \& Annette Baker Fox, Municipal Government and Special-Purpose Authorities, 207 AnNAls AM. ACAD. POL. \& Soc. SCI. 176 (1940); Peter R. Nehemkis, Jr., The Public Authority: Some Legal and Practical Aspects, 47 YALE L.J. 14 (1937); Jerome Shestack, The Public Authority, 105 U. PA. L. REV. 533 (1957).

6. Nehemkis, supra note 5, at 14 n.2.

7. Shestack, supra note 5 , at 556 .

8. See Fox \& Fox, supra note 5, at 178 (explaining that it was much easier to create an SPE than to remove a constitutional debt limit, and noting that SPEs were in part created to solve jurisdictional issues that arose because "political boundaries . . . never coincide with social and economic boundaries"); see also Governmental AcCounting Standards BD. (GASB), Statement No. 14: The FINANCIAL REPORTING ENTITY III 5-7 (1991) (noting that separate organizations are sometimes created to overcome state constitutional, statutory, or charter obstacles or to provide a level of autonomy not permitted by the "general government's organizational framework"). These paragraphs are not impacted by GASB Statement No. 61's amendments to Statement No. 14. For a comparison of the amendments to the original text, see GASB, EXPOSURE DRAFT, ThE FinANCIAL REPORTING ENTITY: AN AMENDMENT OF GASB STATEMENTS No. 14 AND No. 34 III 24-53 (2010).

9. For an introduction to corporate SPEs, see Steven L. Schwarcz, Enron and the Use and Abuse of Special Purpose Entities in Corporate Structures, 70 U. CIN. L. REV. 1309 (2002) [hereinafter Schwarcz, Special Purpose Entities in Corporate Structures]. Corporate finance that involves the use of corporate SPEs is often referred to as structured finance. See id. at 1314. Structured finance in which corporate SPEs issue securities to investors and use the proceeds to purchase financial assets, collections on which are used to repay the securities, is referred to as securitization. See Steven L. Schwarcz, What Is Securitization? And for What Purpose?, 85 S. CAL. L. REV. (forthcoming 2012) (manuscript at 7), available at http://ssrn.com/abstract=1996670. 
the repayment obligation of the SPE is not required to be disclosed as a liability on the balance sheet of the SPE's creator. ${ }^{10}$

This trend in the use of state SPEs is troubling. By reducing financial transparency, off-balance-sheet financing undermines financial integrity and creates a potential for abuseillustrated in the corporate context, for example, by Enron's use of SPEs for balance-sheet manipulation. ${ }^{11}$ Off-balance-sheet financing can even trigger systemic consequences. ${ }^{12}$ Its use by corporate SPEs is seen, for example, as a contributing cause of the 2008 financial crisis. ${ }^{13}$ The lack of transparency can also have other serious consequences, such as preventing state general obligation bonds from being priced correctly based on state fiscal risk. ${ }^{14}$

This Article examines state SPEs and their functions, comparing them to corporate SPEs. Although the use of state SPEs is not inherently wrongful, ${ }^{15}$ they have a greater potential to be

10. See Schwarcz, Special Purpose Entities in Corporate Structures, supra note 9 , at 1301,1315 (describing the relationship between an SPE and its creator and explaining its "use[] to keep debt off a company's balance sheet").

11. Id. at $1309-12$.

12. See infra notes 89-92 and accompanying text (comparing systemic risk resulting from corporate SPE and state SPE use); $c f$. Iman Anabtawi \& Steven L. Schwarcz, Regulating Systemic Risk: Towards an Analytical Framework, 86 NoTRE DAME L. ReV. 1349, 1359 (2011) (observing that Enron's use of SPEs could have triggered a systemic financial crisis if Enron's viability had more closely correlated with the viability of other financial institutions).

13. See, e.g., JoInt ECON. Comm., 110Th Cong., The U.S. Housing BubBLE AND THE Global FinANCIAL CRISIS: Vulnerabilities of the AlternaTIVE FINANCIAL SYSTEM 5, 16-17 (2008), available at http://www.jec.senate .gov/republicans/public/?a=Files.Serve\&File_id=b54b89ff-649e-4e45-93f0

-395d1f507762; MARK JiCKLING, CONG. RESEARCH SERV., RL34412, AVERTING FINANCIAL CRISIS 2-5 (2008), available at http://fpc.state.gov/documents/ organization/103688.pdf; MARTIN NEIL BAILY ET AL., INITIATIVE ON BUS. \& Pub. Policy at Brookings, The ORIGins of the Financial CRisis 27-29 (2008), available at http://www.brookings.edu/ /media/research/files/papers/ 2008/11/origin\%20crisis\%20baily\%20litan/11_origins_crisis_baily_litan; Niall Ferguson, Wall Street Lays Another Egg, VANITY FAIR, Dec. 2008, at 190, 198200; What Went Wrong, ECONOMIST (Mar. 19, 2008), http://www.economist .com/node/10881318.

14. To the extent investors in state general obligation bonds are unaware of de facto guaranteed state SPE debt (and of the fiscal impact of those de facto guarantees on the state), those bonds would almost certainly be mispriced.

15. See Schwarcz, Special Purpose Entities in Corporate Structures, supra note 9 , at 1314 (beginning an inquiry into differentiating legitimate and illegitimate uses of corporate SPEs). In the 2008 financial crisis, for example, the problem was not the use of corporate SPEs, per se. Rather, non-traditional asset-backed securities, collateralized debt obligation (ABS CDO) securitization transactions, which relied on corporate SPEs, were structured in a way that 
abused in public finance than in corporate finance. Several factors contribute to this aggravated potential. Reduced transparency of state SPEs, like corporate SPEs, can undermine financial integrity. Unlike corporate SPEs, however, reduced transparency of state SPEs can also undermine constitutional and democratic legitimacy. ${ }^{16}$ Moreover, state SPEs are more likely to be misused than corporate SPEs because public finance is more susceptible than corporate finance to monitoring failures. ${ }^{17}$

even relatively small errors in cash flow projections could cause defaults and downgradings. When these errors occurred, the resulting defaults and downgradings panicked investors, who started avoiding the debt markets, in turn causing the price of debt securities to fall, which in turn (because of mark-to-market accounting) caused market prices to plummet further downward in a death spiral. The lack of debt financing meant that companies could no longer grow-and in some cases, even survive-affecting the real economy and, at least in part, contributing to the financial crisis. See The State of Securitization Markets: Hearing Before the Subcomm. on Secs., Ins., \& Inv. of the S. Comm. on Banking, Hous., \& Urban Affairs, 112th Cong. 33-34 (2011) (statement of Steven L. Schwarcz, Stanley A. Star Professor of Law and Business, Duke University School of Law) [hereinafter Testimony of Schwarcz], available at http://www.gpo.gov/fdsys/pkg/CHRG-112shrg70772/pdf/CHRG-112shrg70772 .pdf; see also Steven L. Schwarcz, Protecting Financial Markets: Lessons from the Subprime Mortgage Meltdown, 93 MINN. L. REV. 373, 376 (2008) (explaining the interrelated nature of securities such as ABS CDO transactions and SPEs).

16. Cf. Carolyn Bourdeaux, A Question of Genesis: An Analysis of the Determinants of Public Authorities, 15 J. PUB. ADMIN. RES. \& THEORY 441, 442 (2005) (observing that state SPEs are used to "escape [state] debt limitations and possibly to circumvent tax and expenditure limitations"); Rosenbloom, supra note 5, at 871,900 (noting the "ability of public authorities to evade many of the good governance checks applicable to public agencies such as oversight and accountability" and proposing a unified regional overseer and setter of policy for public services provided by state SPEs).

17. Rosenbloom, supra note 5, at 898-99 (noting that state SPEs lack key regulatory features present in corporate SPEs-such as shareholders and market forces-resulting in diminished oversight and increased potential for abuse and corruption). This Article does not engage the question of federal government use of SPEs, which is much more limited than state government use of SPEs. For example, in order to stabilize and bring liquidity back to the commercial paper markets during the 2008 financial crisis, the Board of Governors of the Federal Reserve System (Fed) created, among other facilities, the Commercial Paper Funding Facility (CPFF) to operate as a lender of last resort for those markets. Because the Fed traditionally used its lender-of-lastresort powers under section 13(3) of the Federal Reserve Act to only make loans to banks, it structured the CPFF as a series of Fed loans to State Street Bank and Trust Company, which then made back-to-back loans to a newlycreated special-purpose entity, CPFF LLC. CPFF LLC used the back-to-back loan proceeds to purchase commercial paper from corporations and other commercial paper issuers. Tobias Adrian, et al., The Federal Reserve's Commercial Paper Funding Facility, FRBNY ECON. POL'Y REV., May 2011, at 25, 
This Article proceeds as follows. Part I provides a taxonomy of state SPEs, explaining their distinguishing characteristics. Part II then examines the potential illegitimacies of state SPEs, focusing on their use to remove transparency from public financing. Part III analyzes how regulation should control these potential illegitimacies, arguing that any regulatory framework should embrace at least four overarching organizing principles: improving transparency of state SPE debt, improving monitoring of state SPE debt, limiting state SPE debt, and improving state SPE governance. Part III also demonstrates how a Model Public Authorities Oversight Law ${ }^{18}$ incorporating these principles could be applied to improve state SPE governance and public finance.

\section{STATE SPE TAXONOMY}

One must first understand state SPEs in order to analyze them. Although there are "many conflicting definitions of what [state SPEs] are," important characteristics. These characteristics include engaging in interstate government operations and running programs as an integral part of state government. They also include, less benignly, avoiding constitutional debt limits, avoiding federal taxes, and reducing state financial transparency.

\section{A. Engaging In Interstate FunCtions}

Some state SPEs are created by interstate agreement to address governmental functions crossing state lines. Indeed, one of the most well-known state SPEs is the Port Authority of New York and New Jersey, which operates "America's busiest airport system [JFK, LaGuardia, and Newark airports], marine terminals and ports, the PATH rail transit system, six tunnels and bridges between New York and New Jersey, the Port Authority Bus Terminal in Manhattan, and the World Trade Cen-

30-31. For a thoughtful introduction to the federal government's use of SPEs, see Cheryl D. Block, Congress and Accounting Scandals: Is the Pot Calling the Kettle Black?, 82 NEB. L. REV. 365, 435-42 (2003). This Article also does not directly engage the question of municipal government use of SPEs. But cf. Model Pub. Auth. Oversight Law, infra app. I (embodying a regulatory framework that in principle could also be applied to SPEs established by municipalities or other government units).

18. See infra app. I (proposing a Model Public Authorities Oversight Law).

19. Howard Frant, Reconsidering the Determinants of Public Authority Use, 7 J. PuB. AdMIN. RES. \& THEORY 571, 575 (1997). 
ter." ${ }^{20}$ State SPEs created by interstate agreement are generally viewed with approval. ${ }^{21}$ Paradoxically, however, they are "fairly unusual." 22

\section{B. Running State Programs as EnTERPRISES}

Some state SPEs are created as "enterprises" to run state programs as an integral part of state government. ${ }^{23}$ These types of state SPEs typically finance their operations by issuing revenue bonds (also called revenue debt), repayable solely from the profits of the enterprise. ${ }^{24}$ Investors in those bonds therefore take the risk that the enterprise will be insufficiently profitable to repay them. They have no legal recourse to the state's general funds or tax revenues, and thus the bonds "are not considered state debt." ${ }^{25}$ The state thereby allocates risks associated with the enterprise to investors willing to take that risk, presumably for a higher interest rate on the bonds.

\section{Avoiding Constitutional Debt Limits}

State SPEs are sometimes created specifically to avoid state constitutional debt limits. ${ }^{26}$ Most state constitutions, "as a result of difficulties in one period or another, place some form of restriction on the creation of legal debt, commonly the need either for voter approval or passage of a constitutional amendment." ${ }^{\prime 2}$ States can avoid these debt limits (and the public ref-

20. See Overview of Facilities and Services, PORT AUTHORITY OF N.Y. \& N.J., http://www.panynj.gov/about/facilities-services.html (last visited Oct. 27, 2012).

21. Shestack, supra note 5, at 569 (observing that the "need for [state SPEs] appears greatest on the bi-state or regional level as a means of handling problems that cross jurisdictional lines"); $c f$. Frant, supra note 19, at 588 (discussing that it "seems plausible that authorities are used because they have desirable organizational properties in certain situations," as suggested by political-economy theories).

22. Telephone Interview with Roger L. Davis, Partner and Chair of the Public Finance Department, Orrick, Herrington \& Sutcliffe LLP (May 27, 2011).

23. Id. (referencing the California Department of Water Resources as an example of a state enterprise SPE). State enterprise SPEs are sometimes also justified on the basis that government "should mimic what a private market in analogous goods would produce," following the Tieboutian model of government-as-firm. Richard C. Schragger, Democracy and Debt, 121 YALE L.J. 860, 885 (2012).

24. Telephone Interview with Roger L. Davis, supra note 22.

25. $I d$.

26. See GASB StATEMENT No. 14, supra note 8, II 6.

27. COHEN, supra note 3 , at 1 . 
erendums needed to modify these limits) by issuing state SPE debt. $^{28}$

\section{Financing Private Projects}

State SPEs are also commonly created to facilitate the financing of private projects within a state through the issuance of tax-exempt bonds. ${ }^{29}$ The state SPE, acting as a "conduit," issues non-recourse bonds and then lends the bond proceeds to the parties constructing the project; investors in the bonds have recourse only to those parties and the project. ${ }^{30}$ Because a state conduit SPE is an instrumentality of the state, interest paid to investors on these bonds is exempt from federal taxation (under the federal municipal bond exemption), even though the conduit SPE is not responsible for repaying those investors. ${ }^{31}$ This elevates form over substance, enabling private parties to obtain low-cost tax-exempt financing. ${ }^{32}$

\section{E. REDUCing State FinANCIAL TRANSPARENCY}

As discussed, state SPEs increasingly have been used in recent years to reduce state financial transparency, generally by engaging in off-balance-sheet financing much as corporate SPEs have been used to reduce corporate transparency. ${ }^{33}$ Reduced transparency not only can mislead the public but also

28. Beverly S. Bunch, The Effect of Constitutional Debt Limits on State Governments' Use of Public Authorities, 68 PUB. CHOICE 57, 66 (1991) (concluding that the "results of this empirical analysis support the literature's claim that [at least one reason that] governments use public authorities [is] to circumvent state constitutional debt limits").

29. Telephone Interview with Roger L. Davis, supra note 22.

30. See id.

31. See I.R.C. $§ 103(a)$ (2006); Telephone Interview with Roger L. Davis, supra note 22 .

32. See Telephone Interview with Roger L. Davis, supra note 22 (observing that the Dormitory Authority of the State of New York is an example of a state conduit SPE). Although an important purpose of corporate SPEs is to issue debt with higher credit ratings than the credit rating on corporate debt, it would not appear that state SPEs could issue debt with higher credit ratings than the credit rating on state general obligation (GO) debt. The higher credit rating on debt issued by corporate SPEs reflects that the financial assets securitized by those SPEs "are usually more creditworthy, and almost always easier to understand and value, than the company itself." Testimony of Schwarcz, supra note 15. Public finance, however, is not as clearly asset based, and state SPEs would lack the taxing power of states and, in contrast to states, could be liquidated.

33. See supra notes $8-13$ and accompanying text. 
can enable government officials to avoid public scrutiny. In New York State, for example,

[s]tatewide, politicians increasingly use [SPEs] as ATMs... withdrawing funds so that they can balance General Fund shortfalls . ... Initially, elected officials exercised some discipline and limited their 'withdrawals' to capital projects which would have a long, useful life, but up front expense. More recently, however, withdrawals are being used for [short-term purposes]. ${ }^{34}$

Off-balance-sheet financing is less tractable to solutions in public finance than in corporate finance because, as will be shown, public finance is more susceptible than corporate finance to monitoring failures. ${ }^{35}$

The taxonomy has shown that state SPEs can have positive utility, such as facilitating interstate arrangements and running state programs in ways that allocate associated risks to investors willing to take those risks. ${ }^{36}$ But they also can have potential illegitimacies.

\section{POTENTIAL ILLEGITIMACIES}

The taxonomy indicates at least three potentially illegitimate uses of state SPEs: to avoid state constitutional debt limits, to avoid taxes by obtaining form-over-substance federal tax exemptions, and to reduce state financial transparency and enable government officials to avoid public scrutiny. ${ }^{37}$ Part II.A addresses the first two illegitimate uses and Part II.B addresses the third.

34. E-mail from Scott Fein, Partner, Whiteman Osterman \& Hanna LLP and Dir., Pub. Auths. Project of the Gov't Law Ctr., Albany Law Sch., to author (Aug. 31, 2011) (on file with author).

35. See infra Part II.B.3.

36. State SPEs also have had historical benefits:

$[\mathrm{N}]$ otwithstanding the fiscal peril they may pose, [state SPEs] played an important role underwriting the first meaningful urban infrastructure, helped fund the defense effort in both World Wars, and more recently, at least in [New York State], allowed [the State] to expand housing and healthcare for the poor and elderly and implement environmental safeguards .... In the absence of [state SPEs] our State (and Country) would be a different place.

E-mail from Scott Fein, supra note 34.

37. The allocation by states to enterprise SPEs and their investors of risks associated with the enterprise is not illegitimate. To the contrary, the use of SPEs to allocate risks more precisely between creators of SPEs and investors in securities issued by the SPEs is widely recognized as economically desirable. See Testimony of Schwarcz, supra note 15; see also Nehemkis, supra note 5 , at 14 (stating that where a state SPE "depends for economic survival upon its own earnings rather than upon [state] legislative largess, a greater degree of operating efficiency results"). 


\section{A. Constitutional Illegitimacy AND TAX Avoidance}

Although state SPEs are sometimes used to avoid constitutional debt limits in state constitutions, at least some of these limits would not support the increased functions of modern state government and hence are "obsolete." ${ }^{38}$ Without the ability to get around these limits, many states "would barely be able to function." ${ }^{39}$ Although a more democratic way of addressing the limits would be to amend state constitutions to increase or remove them, ${ }^{40}$ the longstanding use of state SPEs to bypass obsolete debt limits is not this Article's central concern.

Similarly, the use of state conduit SPEs to take advantage of the federal municipal bond tax exemption is relatively straightforward, at least from the standpoint of state public finance. The interesting question is why this federal tax exemption, unlike most other U.S. Internal Revenue Code exemptions, ${ }^{41}$ respects form over substance. Answering that question, however, would primarily be a federal tax law inquiry and thus is beyond this Article's scope.

\section{B. REDUCing Transparency and Avoiding Public ScRutiny}

The most troubling use of state SPEs is their increasing use to reduce financial transparency and enable government officials to avoid public scrutiny. Consider transparency. Rating agencies and the public rely heavily on state financial statements. ${ }^{42}$ The balance sheet-also called, in public finance, a statement of net assets-is central because it shows the state's assets and liabilities. ${ }^{43}$

38. Frant, supra note 19 , at 574.

39. Telephone Interview with Roger L. Davis, supra note 22.

40. Frant, supra note 19, at 574.

41. See Gregory v. Helvering, 293 U.S. 465, 469-70 (1935) (holding that, for federal tax purposes, a transaction's substance is to be considered over its form); see also IRC \$ 183: Activities Not Engaged in For Profit (ATG), IRS.GOV, http://www.irs.gov/Businesses/Small-Businesses-\&-Self-Employed/IRC-\%C2\% A7-183:--Activities-Not-Engaged-in-For-Profit-\%28ATG\%29 (last updated Aug. 3,2012 ) ("The examiner needs to consider the substance of the facts." (emphasis added)).

42. $C f$. Moody's Investors Serv., Moody's State Rating MethodoloGY 11-12 (2004) (stating that "Moody's relies heavily on audited GAAP [state] financial statements").

43. See GASB, Statement No. 14: Basic Financial Statements AND MANAGEMENT'S DISCUSSION AND ANALYSIS-FOR STATE AND LOCAL GOVERNMENTS II 83 (1999). 
State SPE debt is often not shown, however, as balancesheet indebtedness of a state. ${ }^{44}$ On a purely technical level, this makes sense: state SPEs are legally separate units of states, and states rarely guarantee the debt of their units. ${ }^{45}$ States therefore are not usually legally obligated to pay that debt. The story, however, is more complicated.

Most state SPE debt is moral obligation debt, appropriation-contingent debt, revenue debt, or non-recourse debt. ${ }^{46}$ Moral obligation debt means that the state SPE debt is supported by a

reserve fund equal to maximum annual debt service; if the reserve must be drawn down, certification shall be made to the governor (or another appropriate official) who must include a request for the deficiency in the budget. The legislature is under no legal obligation to fund the request, hence the moral appellation. ${ }^{47}$

Appropriation-contingent debt (also called appropriation debt) is different than moral obligation debt insofar as it contemplates the appropriation as the primary source of payment. ${ }^{48}$ It is not technically a legal obligation of the state because the legislature has no legal obligation to fund the appropriation. ${ }^{49}$ Revenue debt is repayable solely from the profits of a state enterprise SPE, and thus legally is not state debt. ${ }^{50}$ And because non-recourse debt is not a legal obligation of the state conduit SPE that issues it, it is not a legal obligation of the state. ${ }^{51}$

State SPE debt that a state is not legally obligated to pay is not ordinarily shown as debt on the state's balance-sheet. Occasionally, state SPE debt is shown in a separate column as indebtedness of the state's "component units." 52 However, the relevant state accounting principles, promulgated by the Governmental Accounting Standards Board (GASB), require this disclosure only for debt of state SPEs that are both (i) "fiscally dependent" on the state-meaning that the state "either

44. See Telephone Interview with Roger L. Davis, supra note 22.

45. Id.

46. Id. (observing that explicit state guarantees of state SPE debt are "very rare").

47. CoHEN, supra note 3 , at 5 .

48. Telephone Interview with Roger L. Davis, supra note 22.

49. Id.

50. See supra notes $24-25$ and accompanying text.

51. See supra notes 29-32 and accompanying text.

52. See, e.g., JOHN ChIANG, CAL. State CONTROLleR's OfFice, State OF CALIFORNIA COMPREHENSIVE ANNUAL FINANCIAL REPORT FOR THE FISCAL YEAR ENDED JUNE 30, 2010, at 28-29 (2011), available at http://www.sco.ca .gov/Files-ARD/CAFR/cafr10web.pdf. 
has authority over the [state SPE's] budget, the setting of its taxes and charges, or its issuance of debt" ${ }^{353}$-and also (ii) in a non-temporary "financial benefit or burden relationship" with the state. ${ }^{54}$ Thus, if a state is "only required to approve the issuance of revenue bonds for a water district but the water district does not receive a [non-temporary] subsidy" from the state, the water district "would not be considered a component unit" of the state. ${ }^{55}$ Although GASB accounting principles becoming effective in 2012 could be broadly read to permit a state to report state SPE financing obligations-even absent any legal obligation by the state with respect to financing-such reporting will not be mandated. ${ }^{56}$

Accordingly, state SPE debt is rarely shown as debt on state balance sheets and, even when shown (usually in a separate column as indebtedness of the state's component units), ${ }^{57}$ may not be easily discernible. In 2006, for example, New York State's financial statements showed $\$ 48.5$ billion of debt but failed to show another $\$ 80$ billion of state SPE debt. ${ }^{58}$

This "off-balance-sheet" nature of state SPE debt can be misleading, however, if the state ultimately backstops the SPE debt. As discussed below, states often have strong economic and reputational motivations to backstop the debt of their SPEs, notwithstanding the absence of a legal obligation to do so.

53. GASB, GASB Statement Concludes Review of Standards DefinING THE FINANCIAL REPORTING ENTITY 2 (2011), available at http://www.gasb .org/cs/BlobServer?blobkey=id\&blobwhere=1175822186077\&blobheader=appli cation $\% 2 \mathrm{Fpdf} \&$ blobcol=urldata\&blobtable=MungoBlobs.

54. Id.

55. Id. at 2-3 (using the example of a water district of a county, and assuming that the water district does not itself "provide resources to the county" other than indirectly by virtue of managing the county's water resources).

56. For example, GASB provides discretion to a primary government to include organizations that "do not meet the specific financial accountability criteria" as component units if doing so would "prevent the reporting entity's financial statements from being misleading." GASB, EXPOSURE DRAFT, supra note 8, II 39.

57. See supra note 52 and accompanying text.

58. See NYS Debt Facts, N.Y. ST. OFF. ST. COMPTROLLER, http://osc.state .ny.us/debt/debtfacts.htm (last visited Oct. 27, 2012); see also THOMAS P. DiNAPOLI, OfFice of State COMPTROLleR, STATE OF N.Y. COMPREHENSIVE ANNUAL FinANCIAL REPORT FOR FISCAL YEAR ENDED MARCH 31, 2010, at 187 (2010), available at http://www.osc.state.ny.us/finance/finreports/cafr10.pdf (neglecting to separate out state SPE debt when identifying types of outstanding debt ratios). 


\section{De Facto "Guarantees"}

A state will often have strong economic motivations to backstop the debt of its SPEs. Except arguably in the case of non-recourse debt of state conduit SPEs, ${ }^{59}$ a default on such debt would signal uncertainty as to whether the state will pay its debts generally, thereby jeopardizing the state's credit rating. ${ }^{60}$ For example, in 1984 the State of Ohio stood behind its water development authority's revenue debt in order to reduce rating-agency scrutiny of a technical default on that debt. ${ }^{61}$ Markets and investors likewise believe that the economic compulsion to avoid increased borrowing costs resulting from a default on state SPE debt provides "enough incentive for the state to pay" that debt to avoid an authority default. ${ }^{62}$ Some courts have therefore ruled that (non-conduit) state SPE debt constitutes debt of the state for constitutional purposes. ${ }^{63}$

There are several other reasons why a state may decide to support payment of its state SPE debt, even though the state is not legally obligated to do so. Because state SPEs often operate as an integral part of state government, ${ }^{64}$ the state may have no practical choice but to support the SPE in order to support the government services performed by the SPE-essentially a "too-important-to-fail" variant of the corporate notion of too-big-

59. Telephone Interview with Roger L. Davis, supra note 22.

60. Cf. Moral Obligation Bonds, StandARD \& PoOR's (June 27, 2006, 12:26 AM), http://www.standardandpoors.com/prot/ratings/articles/en/us/? articleType=HTML\&assetID=1245334963892 (observing that if "a properly structured moral obligation defaulted, despite clear original legislative support, the state's willingness to pay on its other debt would need to be examined").

61. E-mail from W. Bartley Hildreth, Professor of Pub. Mgmnt. \& Policy, Ga. State Univ. Andrew Young Sch. of Policy Studies, to author (Apr. 25, 2011) (on file with author).

62. Telephone Interview with Roger L. Davis, supra note 22; see also Email from Scott Fein, supra note 34 ("Your observation about credit issues associated with default is in this State [New York] absolutely correct. Moral obligation bonds[] are, as you know, referred to on Wall Street as 'feel good bonds' . . . they allow the State to feel good that it's not really increasing the State's aggregate debt and Wall Street to feel good that moral obligation debt is really GO debt in different clothing. Both know that although it may only be a moral commitment ... a default would, as you pointed out in your discussion of the UDC [see infra note 75 and accompanying text], run the risk of curtailing the capital markets to the State.").

63. Telephone Interview with Roger L. Davis, supra note 22 (observing that "two or three states" have case law holding this, although "about onehalf" of the states have case law holding to the contrary).

64. See supra note 23 and accompanying text (discussing enterprise SPEs). 
to-fail. In a federal context, for example, the government recently supported payment of Fannie Mae and Freddie Mac's debt in order to promote stability and liquidity in the housing markets. ${ }^{65}$ This not only constitutes a de facto guarantee but also suggests that state SPEs considered by their managers to be too important to fail might engage in morally hazardous behavior.

A state also may support payment of an SPE's debt in order to honor a moral obligation. This is especially likely to occur where the state SPE has issued moral-obligation debt. It also could occur, however, where the state has issued appropriationcontingent debt since there "remains a potential moral obligation" to fund the appropriation. ${ }^{66}$

Additionally, a state may support payment of an SPE's debt merely to protect the state's reputation more generally. In a corporate context, for example, at the outset of the $2008 \mathrm{fi}$ nancial crisis many banks backstopped their affiliated structured investment vehicles (SIVs) solely to protect the banks' reputations. ${ }^{67}$ In the case of Citigroup, this occurred notwithstanding that it reduced the capital ratio that regulators monitor to gauge that bank's ability to withstand losses on bad loans ${ }^{68}$ and caused Moody's to lower the bank's long-term credit rating. ${ }^{69}$ The reputational harm of not supporting payment of an SPE's debt may be even greater in a state than a corporate context because "investor perception of an implicit ... government guarantee is hard to break," even by "statutory dis-

65. Lorraine Woellert \& John Gittelsohn, Fannie-Freddie Fix at $\$ 160$ Billion with \$1 Trillion Worst Case, BlOOMBERG NEWs (June 13, 2010), http:// www.bloomberg.com/news/2010-06-13/fannie-freddie-fix-expands-to-160-billion -with-worst-case-at-1-trillion.html.

66. See E-mail from W. Bartley Hildreth, supra note 61 (stating that even with appropriation-contingent debt there "remains a potential moral obligation," and observing that a moral-obligation argument was used "against the Governor's hesitancy to get involved with the bond rating analysts' questions" about whether the state would support a state SPE's debt).

67. Shannon D. Harrington \& Elizabeth Hester, Citigroup to Consolidate Seven SIVs on Balance Sheet (Update3), BLOOMBERG NEWS (Dec. 13, 2007), http://www.bloomberg.com/apps/news?pid=21070001\&sid=aT0Ix2iDnZRk (reporting that Citigroup Inc. did this in the amount of $\$ 49$ billion, following similar decisions by HSBC Holdings PLC and WestLB AG to backstop their SIVs).

68. Id.

69. Id. (reporting a lowering from Aa2 to Aa3).

70. Block, supra note 17, at 437 (referencing investor perception of an implicit U.S. government backing of Fannie Mae's debt). 
claimers and [prospectus] disclosures" that the SPE debt is not backed by the government. ${ }^{71}$

For all of these reasons-to avoid jeopardizing its credit rating, to support government services performed by an SPE, to honor its moral obligations, and to generally protect its reputation-a state may well backstop the debt of its SPEs notwithstanding the absence of a legal obligation to do so. State financial statements that do not transparently disclose that debt and the state's de facto guarantee thereof would be misleading. As discussed, however, states rarely make that disclosure in their financial statements. ${ }^{72}$

\section{Consequences of Lack of Transparency}

The lack of transparency can undermine public finance and also make it even more likely that states will continue to manage their financial affairs with insufficient regard to their ability to repay debts. ${ }^{73}$ That ability is not unlimited, even under a state's taxing power. At some point, an increase in the tax rate will cease to raise tax revenues because taxpayers will lose the incentive to earn income, engage in more tax planning to reduce their effective tax rate, or move to other states, causing economic output (and tax revenues) of the troubled state to decline further. ${ }^{74}$ The state ultimately may have to cut back on essential services; and creditors-even those whose debt claims are backed by the state's full faith and credit-may suffer losses if the state, unable to raise sufficient tax revenues to repay its obligations, is forced to restructure its debts.

Lack of transparency can also create financial contagion due to investor difficulty in distinguishing among types of state debt. For example, as a result of the 1975 default by a New

71. Id. (referencing statutory disclaimers and prospectus disclosures that Fannie Mae's debt is not backed by the U.S. government). In 1963, for example, the City of Chicago paid eighty percent of the back interest on bonds issued by the Calumet Skyway Authority due to a "feeling that a bond default by the Authority might damage the city's overall bond rating." MiTCHELL, supra note 4, at 97 (citations omitted).

72. See supra note 57 and accompanying text.

73. Cf. State and Municipal Debt: The Coming Crisis?: Hearing Before the Subcomm. on TARP, Fin. Servs., \& Bailouts of Pub. \& Private Programs of the H. Comm. on Oversight \& Gov't Reform, 112th Cong. 4 (2011) (statement of Rep. Patrick McHenry, Chairman, Comm. on Oversight \& Gov't Reform) (observing that the "vast majority of states now find themselves in a fiscal straightjacket").

74. Steven L. Schwarcz, A Minimalist Approach to State "Bankruptcy", 59 UCLA L. REV. 322, 327 (2011) [hereinafter Schwarcz, State Bankruptcy]. 
York State SPE (the Urban Development Corporation) on its moral obligation bonds, ${ }^{75}$ financial markets shut off financing for all New York State bonds. ${ }^{76}$ Federal backing was ultimately required to allow the state to return to the bond markets. ${ }^{77}$

Additionally, lack of transparency can mislead not only investors but also citizens as to real costs. In a prominent example, a state SPE (the Washington Public Power Supply System, commonly known as WPPSS) issued revenue bonds in order to finance the construction of two power plants. ${ }^{78}$ The revenue bonds were secured by contracts with local utility districts to purchase the resulting electricity. ${ }^{79}$ Unknown to residents, ${ }^{80}$ the utility districts agreed to support payment of the bonds even if the plants were never completed. ${ }^{81}$ Due to cost overruns, the plants were not, in fact, completed, ${ }^{82}$ leaving the utility districts-and thus residents of those districts-as the deep pockets for payment. ${ }^{83}$

Finally, lack of transparency can impose an unforeseen burden on out-of-state taxpayers. This could occur, for example, if the federal government, as a result of increasingly negative

75. The UDC, tasked with building low cost housing throughout the state, was given authority to issue $\$ 2$ billion worth of bonds backed by the moral obligation of the state. But, due largely to inept management, the authority was unable to repay its debt. DONALD AXELROD, SHADOW GOVERNMENT 74 (1992).

76. Id. at 72-80. The contagion effect may have been exacerbated by New York City's concurrent financial crisis. Id.

77. Id. at 81 .

78. Id. at $66-69$.

79. Id.

80. Id. at $67,101$.

81. Id. at 67 (observing that the local utility districts were required to service WPPSS bonds regardless of whether the plants became operational). It is unclear why the utility districts did not disclose their effective guarantees of the WPPSS bonds. The likely reason is that accounting principles do not always require disclosure of contingent guarantees. See Fin. Accounting STANDARDS BD. (FASB), STATEMENT OF FINANCIAL ACCOUNTING STANDARDS NO. 5: ACCOUNTING FOR CONTINGENCIES III 2-3, 8 (1975). These paragraphs were not affected by subsequent proposed amendments. FASB, EXPOSURE DRAFT, Disclosure OF CERTAIN LOSS CONTINGENCIES 16-20 (2008). Axelrod asserts the lack of disclosure was a result of WPPSS not being answerable to any of the democratic institutions in the state. AXELROD, supra note 75, at 101. But that does not explain why the utility districts did not themselves make the disclosure.

82. AXELROD, supra note 75 , at 67 .

83. The utility districts, at the behest of residents, then sued WPPSS to challenge the legality of the contracts and prevent being forced to pay for plants that were never completed. $I d$. at 69. A politicized Supreme Court of Washington sided with the utility districts and voided the contracts. Id. Without revenue to support the bonds, WPPSS defaulted. Id. 
state fiscal conditions, ${ }^{84}$ is called on to bail out a state's SPE debt. $^{85}$

\section{Comparing State and Corporate SPE Lack of Transparency}

The analysis above has shown that the use of state SPEs can reduce a state's financial transparency, with egregious consequences for the state, its residents, its creditors, and potentially the federal government (and thus taxpayers throughout the country). The Article next compares those consequences with the consequences of the lack of transparency caused by corporate SPEs.

A lack of transparency caused by corporate SPE debt can lead to companies unexpectedly failing and can also have systemic consequences to the financial system. ${ }^{86}$ For these reasons, Congress and the SEC have devoted significant attention to an appropriate regulatory framework. ${ }^{87}$

The lack of transparency caused by state SPE debt can similarly lead, as discussed, to unexpected state financial problems. ${ }^{88}$ That lack of transparency might also have systemic consequences; by undermining governmental financial integrity, it could infect government securities markets. ${ }^{89}$ Although it would appear that systemic consequences could be greater in a corporate than a state context because markets for corporate debt

84. Many states are believed to be at or near crisis levels of debt. See, e.g., Mary Williams Walsh, State Debt Woes Grow Too Big to Camouflage, N.Y. TiMES, Mar. 30, 2010, at A1, available at http://www.nytimes.com/2010/03/30/ business/economy/30states.html?pagewanted=1. Several of these states, such as New York and California, are also some of the heaviest issuers of SPE debt. The recession is expected to only continue to negatively impact state's fiscal conditions. See PhIL Oliff ET AL., CTR. ON Budget \& Policy PRIORITIES, States Continue to FEel ReCESSION'S ImPACT 1 (2012), available at http://www.cbpp.org/files/2-8-08sfp.pdf.

85. Many believe that the most heavily indebted states will require a bailout or a type of assisted bankruptcy from the federal government. See, e.g., Mary Williams Walsh, A Path Is Sought for States to Escape Debt Burdens, N.Y. TIMES, Jan. 21, 2011, at A1, available at http://www.nytimes.com/2011/ 01/21/business/economy/21bankruptcy.html?pagewanted=all. Unforeseen state SPE debt would need to be addressed if, for example, the state relies on the indebted SPEs for essential services.

86. See supra notes $12-13$ and accompanying text.

87. See infra Part III.B.

88. See supra notes 73-85 and accompanying text.

89. Compare Steven L. Schwarcz, Systemic Risk, 97 GEO. L.J. 193 (2008) (examining systemic consequences of corporate financial failures), with Schwarcz, State Bankruptcy, supra note 74 (examining systemic consequences of state financial failures). 
are larger than markets for state debt, ${ }^{90}$ any comparison of consequences must be qualified by the possibility of correlations between those markets. A loss of confidence in, or a collapse of, government securities markets could trigger a broader lack of confidence or collapse of debt markets, possibly affecting the markets for corporate debt securities. A somewhat parallel event occurred in 2008 when a collapse of the mortgage-backed securities market triggered the broader collapse of virtually all markets for debt securities. ${ }^{91}$ Similarly, the current European Union sovereign debt crisis is believed to have the potential to trigger broader systemic consequences. ${ }^{92}$

Therefore, as with corporate SPE debt, attention should be given to creating an appropriate regulatory framework for problems of state SPE debt. Indeed, the need for such a regulatory framework may even be greater in the state than the corporate context. States may have a greater inherent propensity than corporations to want to use SPEs to raise off-balancesheet debt. Because states, unlike corporations, cannot "fail" in the sense of being forced to liquidate, they lack that deterrent against non-transparent use of SPEs. ${ }^{93}$

Furthermore, state public finance is more susceptible than corporate finance to monitoring failures. States are monitored

90. In the second quarter of 2011 , there was reportedly $\$ 7.8$ trillion of corporate debt outstanding in the United States, versus only $\$ 2.9$ trillion of state and municipal debt. Outstanding U.S. Bond Market Debt, SIFMA.ORG (June 8, 2012), http://www.sifma.org/uploadedFiles/Research/Statistics/ StatisticsFiles/CM-US-Bond-Market-Outstanding-SIFMA.xls.

91. Anabtawi \& Schwarcz, supra note 12, at 1359-61.

92. See, e.g., How to Save the Euro, ECONOMIST, Sept. 17, 2011, at 11, available at http://www.economist.com/node/21529049 (“As credit lines gum up and outsiders plead for action, it is not just the euro that is at risk, but the future of the European Union and the health of the world economy. . . . A Greek default would threaten many banks, not just in Greece: this week the markets took aim at French banks that hold southern European debt."). Corporate counterparty risk, on the other hand, is more likely to have a systemic impact than governmental counterparty risk because corporate viability is more likely to be closely correlated than governmental viability since governments cannot be liquidated. $C f$. supra note 13 and accompanying text (discussing the relationship between systemic risk and the correlation of financial viability).

93. Cf. Block, supra note 17, at 369-70 (observing that the risk of bankruptcy provides at least a "modest[] check on corporate accounting gimmicks," but lacking bankruptcy, "temptations for the government to engage in creative accounting may be even greater than those in the private sector"). Even though states cannot be liquidated, they still will have significant incentives to avoid default. It is unclear, though, whether those incentives are as strong as the incentive to avoid liquidation, and thus whether they are as likely to encourage sound financial choices. 
by residents and creditors. ${ }^{94}$ Corporations, in contrast, are monitored by shareholders and creditors. ${ }^{95}$ Creditors monitor only to the limited extent of their negotiated covenants, and covenants in state debt are even more limited than covenants in corporate debt. ${ }^{96}$ Therefore creditor monitoring of state SPE debt is likely to be even more limited than creditor monitoring of corporate SPE debt.

States are also monitored by residents, who have even less incentive to monitor than most creditors. Unlike creditors, few if any state residents are likely to have sufficient amounts at stake to justify the cost of monitoring. ${ }^{97}$ The ability of state residents to freely choose to move to another state, notwithstanding some cost in doing so, may well further reduce their incentive to monitor. ${ }^{98}$ Furthermore, residents who wish to monitor state SPE debt may find themselves unable to correct problems revealed by the monitoring. For example, after voters in New York State rejected a $\$ 500$ million bond issue in November

94. See, e.g., Rosenbloom, supra note 5, at 872-74 (noting that while corporations are accountable to shareholders and creditors, public authorities do not have shareholders, and the public has no shareholder enforcement mechanisms).

95. Id. at $872-73$ ("[C]orporations are scrutinized and evaluated by numerous groups such as investors, government entities and shareholders.").

96. Id. at 878 (discussing the oversight that corporate shareholders and creditors have over the actions of corporations, but there is no group that has "taken on the shareholder[] role" in the context of public authorities). Covenants in state debt may be more limited than covenants in corporate debt because states, unlike corporations, have taxing power and cannot be liquidated. Recently there has been discussion of adding covenants to state debt securities in an effort to exert fiscal discipline. See, e.g., Ted Phillips, Control by Covenant, BOND BUYER, Mar. 18, 2010, at 1, 6, available at http://www.bondbuyer .com/issues/119_301/new_york_state_budget-1009673-1.html?zkPrintable= true (reporting plan of New York Lieutenant Governor Richard Ravitch to include "an event of default if the review board found the budget out of balance, and neither the Legislature nor the governor took steps to return it to balance"); Yvette Shields, Experts Weigh in on Fixing Illinois, BOND BUYER, June 30, 2011, at 1, 8, available at http://www.bondbuyer.com/issues/119_373/ illinois_budget-1014194-1.html?zkPrintable=true.

97. See, e.g., Rosenbloom, supra note 5, 881-82 ("[T] he public has significantly less voting power, enforcement rights and political power than private shareholder investors in private corporations .... In many ways, avoiding public participation is the reason public authorities are created.").

98. The WPPSS debacle also shows that residents may not even become aware of problems until too late. See supra notes 78-83 and accompanying text (observing that residents of local utility districts were not informed that those districts had effectively guaranteed payment of WPPSS bonds). The residents only became aware of the problem after electricity costs rose to pay for the cost of those bonds. AXELROD, supra note 75, at 69 (discussing a "consumer revolt" after electricity rates increased greatly). 
1981, the State directed one of its SPEs, the Urban Development Corporation, to issue the bonds. ${ }^{99}$ A citizens' lawsuit to stop that bond issuance was dismissed by a court as lacking standing because the New York State Constitution gave voters the right to approve only the issuance of bonds issued by the "[s]tate." 100

In contrast, corporations are monitored by shareholders in addition to creditors. Shareholders can have concentrated holdings, and they face few if any legal obstacles to monitoring and enforcement. ${ }^{101}$ Moreover, shareholders have a greater incentive than creditors to monitor because shareholders are residual claimants who would lose money before creditors. ${ }^{102}$

In short, creditor monitoring of states and corporations is limited. Shareholder monitoring helps fill that shortfall for corporations, but resident monitoring is unlikely to fill that shortfall for states. The resulting monitoring insufficiency may make it even more likely that states (as compared to corporations) will use SPEs to hide debt. ${ }^{103}$

\section{Undermining Democratic Control of State Functions}

Although not the primary focus of this Article, it should be noted that another significant difference between state SPEs and corporate SPEs is the potential for state SPEs to undermine governmental legitimacy. State SPEs are usually "governed by an appointed board with policymaking and budgetary independence from the state... that created them."104 One commentator describes these entities as creating "a hidden

99. AXELROD, supra note 75 , at 122 .

100. Id. at $122-23$.

101. See Virginia Harper Ho, "Enlightened Shareholder Value": Corporate Governance Beyond the Shareholder-Stakeholder Divide, 36 J. CORP. L. 59, 69 (2010-2011) ("In sum, shareholder activism itself, changing market conditions, and regulatory changes have ushered in a new shareholder-oriented world for public corporations in which more investors are able and willing to take a greater role in shaping corporate decision-making . ..." (emphasis added)).

102. Id. at 102 .

103. Cf. Scott Fein, Would a State Constitutional Amendment Promote Public Authority Fiscal Reform?, 12 N.Y. ST. B.A. Gov'T, L. \& POL'Y J. 52, 53 (2010) (observing that New York State has, in the past, increased issuance of state-supported SPE debt in an effort to avoid the public referenda required for issuance of state debt).

104. Bourdeaux, supra note 16, at 442. State SPEs usually have the "right to sue and be sued, own property, and may have the ability to tax and invoke eminent domain." Id. 
government that is not highly accountable through regular democratic processes." ${ }^{105}$ Others say these entities "function outside the normal framework of government."106

This Article has already discussed how state SPEs are used to circumvent state constitutional debt limits. More broadly, however, state SPEs have been considered a means by which the corporate management structure (and its believed efficiency) could be applied to public-sector management, thereby avoiding political constraints and bureaucratic red tape. ${ }^{107}$ State SPEs are thus not always subject to the types of controls applicable to managers of traditional state government agencies. ${ }^{108}$ For example, competitive bidding procedures-which traditionally are used to diminish favoritism and political corruption in governmental contracting-are not necessarily applicable to state SPEs. ${ }^{109}$ At least one commentator argues that, except for multi-jurisdictional state SPEs, the "benefits" accruing from this supposed corporate efficiency are largely illusory. $^{110}$

The Article next considers how regulation could help to mitigate state SPE abuses, focusing on the problem of state SPE debt.

\section{TOWARDS REGULATORY SOLUTIONS}

Although state SPEs raise many concerns, including concerns over their use to reduce state financial transparency, they do have legitimate uses. Therefore, rather than banning state SPEs outright, regulatory solutions should seek to address the concerns. This Part begins that inquiry by examining recent state SPE reform efforts. It then compares those efforts with recent reforms of corporate SPEs. Thereafter, the Article

105. Id. at 441 (emphasis added); see also Bunch, supra note 28, at 57 (observing, at that time, that " $[\mathrm{m}]$ uch of the literature on public authorities indicates that governments use authorities to circumvent debt limits").

106. Robert G. Smith, The Web of Actors in Authority Policy Implementation, 18 POL'Y STUD. J. 986, 986 (1990).

107. Shestack, supra note 5 , at 555 .

108. For example, responding to the failure of the Massachusetts Housing and Finance Authority and to certain other Massachusetts SPE failures, State Senator Patricia McGovern explained, "[w]hile each authority may have been justified on its own merits, the combined effect of these efforts has been to place the state in a precarious situation where many of its critical functions are performed by autonomous, non-elected governmental units." AxELROD, supra note 75, at 103 (quoting Senator Patricia McGovern).

109. Shestack, supra note 5 , at 565.

110. See id. at 569 . 
develops a broader conceptual framework for regulating state SPEs.

\section{A. ReCEnt StATE SPE REForm EFFortS}

New York State has attempted in recent years to reform its state SPEs. Beginning in 2000, it passed a series of three laws ${ }^{111}$ to "[r] ein[] in New York's [s]ecret [g]overnment." Debt Reform Act of 2000 established statutory limits for the amount and terms of state SPE debt that New York is contractually or constitutionally obligated to pay. ${ }^{113}$ These limits, however, do not address moral obligation debt or debt for which New York is contingently obligated. ${ }^{114}$

In 2005, New York passed the Public Authorities Accountability Act, ${ }^{115}$ which imposed heightened state SPE reporting requirements and stricter governance rules. ${ }^{116}$ And in 2009, New York enacted the Public Authorities Reform Act, ${ }^{117}$ establishing the Authorities Budget Office to review and analyze state SPEs. ${ }^{118}$

111. Wilson \& Eichelberger, supra note 1, at 18-21.

112. OfFICE OF Budget \& Policy ANAlysis, OfFICE OF the STATE ComPTROLLER, PUBlic AUTHORITY REFORM: REINING IN NEW YORK'S SECRET GOVERNMENT (2004), available at http://www.osc.state.ny.us/press/releases/feb04/ publicauthorityreform.pdf.

113. Wilson \& Eichelberger, supra note 1, at 18; see also N.Y. STATE FIN. LAW §§ 67-a, 67-b (McKinney 2011).

114. "State-supported debt" is defined as

any bonds or notes, including bonds or notes issued to fund reserve funds and costs of issuance, issued by the state or a state public corporation for which the state is constitutionally obligated to pay debt service or is contractually obligated to pay debt service subject to an appropriation, except where the state has a contingent contractual obligation.

$\S 67$-a. Furthermore, neither obligations due in less than one year nor those pursuant to annual legislative appropriations are considered "debt" subject to New York state's constitutional requirement for public referenda. 87 N.Y. JUR. 2D PUB. SEC. $§ 10$ (2011) (citing § 67-b(1)(a); Local Gov’t Assistance Corp. v. Sales Tax Asset Receivable Corp., 2 N.Y.3d 524 (2004)).

115. 2005 N.Y. Laws ch. 766.

116. Wilson \& Eichelberger, supra note 1, at 19-20.

117. 2009 N.Y. Laws ch. 506. The legislative findings in section 1 of the Public Authorities Reform Act stated that, even after enactment of the Public Authorities Accountability Act of 2005, "fundamental problems of transparency, accountability, the responsibilities and functions of board members and oversight have not been addressed, leading to a lack of public trust in these institutions." Id. $\S 1$.

118. Wilson \& Eichelberger, supra note 1, at 20-21. 
These reforms have already started bearing fruit. For example, the New York State Comptroller has reported that, "[a]s a result of audit findings and recommendations, and administrative and legislative actions," a number of New York's state SPEs had announced actions to improve their accountability. ${ }^{119}$ The Comptroller also more recently observed that several state SPEs had restructured their bonds after seeking the Comptroller's approval, resulting "in total debt service savings of $\$ 456.9$ million on a cash flow basis and $\$ 175.9$ million on a net present value basis over the life of the bonds." also released reports on the operations of specific state SPEs. ${ }^{121}$

\section{B. RECENT CORPORATE SPE REFORM EFFORTS}

Regulatory efforts to reform the use of corporate SPEs began, in response to Enron's collapse, with promulgation by Congress of the Sarbanes-Oxley Act in $2002^{122}$ and the issuance by the staff of the Securities and Exchange Commission of a 2005 report on off-balance-sheet corporate transactions (SEC Staff Report). ${ }^{123}$ These regulatory efforts then continued, spurred by the 2008 financial crisis, with the Dodd-Frank Act ${ }^{124}$ and the government-agency rulemaking thereunder. ${ }^{125}$

119. OfFice of Budget \& Policy ANAlysis, OfFice of the State CompTroller, Public Authorities in New York State: ACCElerating MomenTUM TO ACHIEVE REFORM 38-39 (2005), available at http://www.osc.state.ny .us/reports/pubauth/pubauthoritiesreform.pdf.

120. Thomas P. DiNAPoli, OfFice of the State Comptroller, Public AUTHORITY DEBT STRUCTURE AND NEW YORK's FUTURE GENERATIONS 1 (2010), available at http://www.osc.state.ny.us/pubauth/reports/pa-debt-struct -092710.pdf.

121. See New York's Public Authorities, OFF. ST. Comptroller, http://www.osc.state.ny.us/pubauth/reports.htm (last visited Oct. 27, 2012) (including reports on the New York State Urban Development Corporation, the Metropolitan Transportation Authority, and the New York State Thruway Authority).

122. Sarbanes-Oxley Act of 2002, Pub. L. No. 107-204, 116 Stat. 745.

123. StAFF OF THE SEC, REPORT AND RECOMMENDATIONS PURSUANT TO SECTION 401(C) OF THE SARBANES-OXLEY ACT OF 2002 ON ARRANGEMENTS With OfF-Balance Sheet Implications, Special Purpose Entities, AND TRANSPARENCY OF FILINGS BY ISSUERS (2005), available at http://www.sec.gov/ news/studies/soxoffbalancerpt.pdf [hereinafter SEC STAFF REPORT]. The SEC Staff Report was informally issued by the SEC staff without formal approval by the SEC's Commissioners; it thus was not an official report of the SEC.

124. Dodd-Frank Wall Street Reform and Consumer Protection Act, Pub. L. No. 111-203, 124 Stat. 1376 (2010).

125. Much of the substance of the Dodd-Frank Act will be realized through administrative rulemaking by the SEC and other federal government agencies. $C f$. Lois L. Weinroth \& Richard L. Fried, Securitization Provisions of the 
The Sarbanes-Oxley Act indirectly addressed improving accounting standards that govern when corporate SPEs should be consolidated with their parent companies. ${ }^{126}$ The SEC Staff Report, however, more directly focused on the use of corporate SPEs to reduce financial transparency. ${ }^{127}$ Observing that "many of the areas dealing with off-balance sheet arrangements involve significant use of accounting-motivated structured transactions" that utilize corporate SPEs,${ }^{128}$ the SEC staff advocated against "transactions and transaction structures primarily motivated by accounting and reporting concerns, rather than economics." ${ }^{129}$ In that connection, the SEC staff urged the Financial Accounting Standards Board (FASB, the corporate equivalent of the GASB) to consider changing corporate accounting principles in order to increase the transparency of corporate SPE debt and also admonished participants in the financial reporting process to become more aware of the problem. ${ }^{130}$ To that end, FASB revoked its Financial Accounting Standard No. 140, which governed off-balance-sheet treatment of certain corporate SPE debt, and replaced it with a more nuanced (although also more ambiguous) test. ${ }^{131}$

The Dodd-Frank Act did not address the use of corporate SPEs per se, instead focusing on their use in securitization transactions. ${ }^{132}$ These are transactions in which corporate SPEs

Dodd-Frank Act, 16 J. STRUCTURED Fin., Fall 2010, at 38, 43 (“[I]t is impossible to predict at this time the full range of regulations that will be applicable to the asset-backed securitization industry.").

126. See Neal Newman, Enron and the Special Purpose Entities-Use or Abuse?-The Real Problem-The Real Focus, 13 LAW \& Bus. REV. AM. 97, 122-23 (2007).

127. See SEC STAFF REPORT, supra note 123, at 3 (identifying a variety of "initiatives to improve transparency ... in the financial reporting process").

128. Id.

129. Id.

130. Id.

131. FASB, Statement of Financial Accounting Standards No. 166: ACCOUNTING FOR TRANSFERS OF FINANCIAL ASSETS AN AMENDMENT OF FASB STATEMENT No. 140 (2009), available at http://www.fasb.org/cs/BlobServer? blobkey=id\&blobwhere $=1175823288480 \&$ blobheader $=$ application\%2Fpdf\& blobcol=urldata\&blobtable $=$ MungoBlobs.

132. Steven L. Schwarcz, Stanley A. Star Professor of Law \& Bus., Duke Univ. Sch. of Law, The 2011 Diane Sanger Memorial Lecture at the SEC Historical Society: Protecting Investors in Securitization Transactions: Does Dodd-Frank Help, or Hurt? (Mar. 28, 2011) (transcript available at http:// c0403731.cdn.cloudfiles.rackspacecloud.com/collection/programs/sechistorical032811-transcript.pdf; audio available at http://www.sechistorical.org/ collection/programs/sechistorical-032811-podcast.mp3) [hereinafter Schwarcz, 2011 Diane Sanger Memorial Lecture]. 
issue securities to investors and use the proceeds to purchase financial assets, collections on which are used to repay the securities. ${ }^{133}$ In that context, Dodd-Frank addressed, essentially, three issues: (1) improving disclosure to investors in the securities about the nature of the underlying financial assets; (2) limiting conflicts of interest between originators of those financial assets and investors in securities issued by corporate SPEs purchasing those assets; and (3) increasing rating agency scrutiny of securitization transactions. ${ }^{134}$ The first two issues have little application per se to state SPEs, which have not been used (and there is no indication they are likely to be used) for securitization transactions. ${ }^{135}$ Nonetheless, the broader goals of Dodd-Frank to improve investor disclosure, to limit conflicts of interest, and to increase rating agency scrutiny have some resonance for state SPEs.

\section{A BROADER CONCEPTUAL FrameWORK FOR REFORM}

These regulatory efforts to reform state and corporate SPEs suggest four overarching organizing principles: improving transparency of state SPE debt; improving monitoring of state SPEs; limiting state SPE debt; and improving state SPE governance. In deriving a broader conceptual framework, this Article first compares whether these principles would address all of the types of negative consequences identified in this Article. ${ }^{136}$ Those consequences can be summarized as follows:

(i) The off-balance-sheet nature of state SPE debt (i.e., that debt is often not shown as a liability on the balance sheets of their sponsoring states) can undermine state financial integrity, making it more likely, for example, that states will continue to manage their financial affairs with insufficient regard to their ability to repay their debts. This can lead to unexpected state financial problems, especially if the state ultimately backstops the SPE debt (and states often have strong economic and reputational motivations to de facto guarantee that debt, notwithstanding the absence of a legal obligation to do so).

133. See supra note 9 and accompanying text.

134. Schwarcz, 2011 Diane Sanger Memorial Lecture, supra note 132.

135. It is not even certain that Dodd-Frank's reforms make sense in the securitization context. See $i d$. If state SPEs were to begin to engage in securitization transactions, regulators could then consider the extent to which DoddFrank's reforms, or possible other reforms, should apply.

136. $C f$. Richard A. Posner, LaW, Pragmatism, and Democracy 59 (2003) (arguing that legal reasoning may not exist as an independent concept, and that what really matters is consequences). 
(ii) The off-balance-sheet nature of state SPE debt might also have systemic consequences by causing a loss of confidence in state and possibly other government securities markets.

(iii) The off-balance-sheet nature of state SPE debt can mislead not only investors-including by creating contagion due to investor difficulty in distinguishing among types of state debt-but also state citizens as to real costs. Furthermore, a federal government bailout of that debt can impose an unforeseen burden on out-of-state taxpayers.

(iv) These consequences can be worse in public finance than in corporate finance because the use of SPEs in public finance is more susceptible to monitoring failures than their use in corporate finance.

(v) The non-representative corporate-style governance of state SPEs can undermine constitutional and democratic legitimacy. It can also generate conflicts that cause a state SPE to incur debt for its own benefit and not necessarily for the state's benefit. ${ }^{137}$

Thus, the negative consequences identified in this Article result from the off-balance-sheet nature of state SPE debt, monitoring failures relating thereto, and state SPE governance failures.

These consequences correlate well to the overarching organizing principles suggested by regulatory efforts to reform state and corporate SPEs. The principle of improving transparency of state SPE debt would address consequences from the off-balance-sheet nature of state SPE debt; the principle of improving monitoring of state SPE debt would address consequences of monitoring failures; the principle of limiting state SPEs debt could address all those consequences; and the principle of improving state SPE governance would address consequences of governance failures.

This Article's conceptual framework for regulatory reform therefore adopts these four overarching organizing principles: improving transparency of state SPE debt; improving monitoring of state SPE debt; limiting state SPE debt; and improving state SPE governance. To apply these principles to actual regulatory reform, I have incorporated the principles into a Model

137. This is not dissimilar to the agency-cost concerns addressed in Schwarcz, Special Purpose Entities in Corporate Structures, supra note 9, and in Steven L. Schwarcz, Conflicts and Financial Collapse: The Problem of Secondary-Management Agency Costs, 26 YALE J. ON REG. 457 (2009). 
Public Authorities Oversight Law (Model Oversight Law), ${ }^{138}$ proposed for enactment by individual states. I next examine how these principles, as articulated in the Model Oversight Law, could be applied.

Before doing so, however, it is worth asking why a state would consider enacting the Model Oversight Law or similar legislation, which would limit the state's ability to continue issuing non-transparent debt through SPEs. One answer is that the state would be increasing its financial transparency, as New York State has been trying to do. ${ }^{139}$ New York has even found that improving the transparency of its SPE debt can, at least in certain cases, save money. ${ }^{140}$ Another answer is that as the problem of state SPE debt becomes more publicly known, states that don't engage in reform will face reputational costs. ${ }^{141}$ These costs might even include increased financing costs as investors become wary of the non-transparent financial condition of reform-averse states. And public and media outcry about the problem might put pressure on GASB to engage in its own effort to further reform government accounting principles for state SPE debt, which would remove the initiative from the states. ${ }^{142}$ Finally, if all else fails, the federal government could consider making state SPE reform a condition of any federal government bailout of a state. ${ }^{143}$ So long as the state ultimately chooses whether to enact the reform, that should not impose an unconstitutional encroachment on state sovereignty. ${ }^{144}$

\section{APPLYING THE FRAMEWORK}

This Part considers each principle in turn, examining how the Model Oversight Law incorporates the principle and how that Law would apply to state SPEs. ${ }^{145}$ To that end, this Part

138. See infra. app. I.

139. See supra notes $112-21$ and accompanying text.

140. See supra note 120 and accompanying text.

141. See supra Part II.B.1.

142. FASB has been trying to do that for corporate accounting principles governing SPE debt. See supra note 131 and accompanying text.

143. See supra note 85 (observing that "[m] any believe that the most heavily indebted states will require a bailout or a type of assisted bankruptcy from the federal government").

144. See Schwarcz, State Bankruptcy, supra note 74, at 336 (explaining why, so long as a "state has the right to decide whether or not to [enact a federally proposed legal framework], its sovereignty would not be impugned"). (footnote omitted)).

145. All references to specific sections in the remainder of the Article refer to the Model Oversight Law in Appendix I. 
examines how the Model Oversight Law incorporates, and would apply to state SPEs, the principles of improving transparency, improving monitoring, limiting debt, and improving governance.

\section{Improving Transparency of State SPE Debt}

The Model Oversight Law seeks to improve transparency in two ways. The customary way of making debt transparent is by requiring balance-sheet disclosure under accounting rules. In the United States, accounting rules are promulgated bypursuant to private ordering in the form of delegation of authority by the Securities and Exchange Commission to-FASB in the case of corporate accounting ${ }^{146}$ and GASB in the case of government accounting. ${ }^{147}$

The Model Oversight Law first attempts to improve transparency by improving balance-sheet disclosure of state SPE debt. Section III.1(b) of that Law requires each state SPE to maintain audited financial statements, certified by independent public accountants as complying with GASB's generally accepted government accounting principles. It also requires each state SPE to deliver copies of these financial statements to the Authorities Oversight Office, an independent state government office created by the Model Oversight Law to oversee state SPEs. Subsection III.1(e) of that Law further requires each state SPE to establish a semi-independent audit committee to provide direct oversight of the accountants' audits.

The Model Oversight Law does not purport to question the government accounting principles promulgated by GASB. This Article suggests, however, that GASB should further examine how its accounting principles should treat balance-sheet disclosure of state SPE debt. One important question, already discussed in this Article, is how to determine when such debt should be disclosed in the first instance. ${ }^{148} \mathrm{~A}$ second question is how state SPE debt, otherwise required to be disclosed, should be disclosed-for example, as a liability on the state SPE's balance sheet, in a separate column of the balance sheet as indebtedness of the state's component units, or merely as a con-

146. See supra notes 129-30 and accompanying text; see also Steven L. Schwarcz, Private Ordering, 97 Nw. U. L. REV. 319, 320 (2002) (discussing this delegation of authority).

147. See supra notes 52-53 and accompanying text.

148. See supra notes 52-55 and accompanying text. 
tingent liability shown in the notes to the balance sheet. ${ }^{149} \mathrm{Be}-$ cause few people actually read financial statement notes, ${ }^{150}$ FASB has been struggling with a similar question in the context of corporate accounting for SPE debt. ${ }^{151}$

The Model Oversight Law's second approach to improving the transparency of state SPE debt is to consider mechanisms that go beyond accounting for such debt to be publicly disclosed. To this end, section II.1(e) of that Law requires the Authorities Oversight Office to assist state SPEs in improving the procedures by which their finances are publicly disclosed, including standardizing disclosure of their liabilities. Standardized disclosure would help to facilitate comparative analysis. Section II.1(i) also requires the Authorities Oversight Office to periodically issue reports on its findings and analyses and, except to the extent proprietary, to make these reports and analyses publicly available.

\section{Improving Monitoring of State SPE Debt}

Improved monitoring is a strong focus of the Model Oversight Law, which creates the Authorities Oversight Office to act as the primary monitor. Section III.1(c) of the Model Oversight Law requires each state SPE to inform the Authorities Oversight Office of its outstanding debt securities, the credit ratings on such debt, and any changes in those credit ratings. This enables the Authorities Oversight Office not only to monitor that debt but also to publicly promulgate information about the debt (thereby also increasing transparency).

Section II.1(h) of the Model Oversight Law requires the Authorities Oversight Office to monitor any defaults on state SPE debt and to find out how the defaults are resolved. Section III.1(d) of that Law ties back into that provision by requiring each state SPE itself to inform the Authorities Oversight Office of defaults on its debt and their resolution. By studying how de-

149. A superficially simple solution would be to mandate balance-sheet disclosure of all state SPE debt, but that might have unintended consequences, such as undermining disclosure by making it too complex. $C f$. Steven L. Schwarcz, Rethinking the Disclosure Paradigm in a World of Complexity, 2004 U. ILL. L. REV. 1, 36-37 (showing that excessive disclosure can undermine its comprehensibility).

150. See Annual CFO Survey, ASs'N Gov't ACCOUnTANTS (July 2008), http://www.agacgfm.org/AGA/Documents/Research/cfosurvey2008-1-.pdf (surveying CFOs and financial executives about the usefulness of financial statements).

151. See supra note 131. 
faults are resolved, the Authorities Oversight Office should be able to ascertain the extent to which the state itself, directly or indirectly, is supporting its SPEs. The Authorities Oversight Office would also be able to make this information publicly available.

The Model Oversight Law further adopts a parallel track to ascertain the extent to which the state itself is supporting its SPEs. Section II.2(b) of that Law authorizes the Authorities Oversight Office to obtain, from any state government source, information and documentation revealing the existence and the nature of any direct or indirect guarantees backed by the state's full faith and credit of state SPE debt. Section III.1(c) of that Law ties back into that authorization by requiring each state SPE itself to inform the Authorities Oversight Office of these guarantees.

Finally, section III.1(g) of the Model Oversight Law contemplates improved state SPE monitoring of its own debt. To this end, that Law requires each state SPE to establish a semiindependent finance committee to review and make recommendations on proposals by the SPE to issue debt.

\section{Limiting State SPE Debt}

To some extent, the finance committee requirement discussed above should help limit state SPE debt at appropriate levels. Section II.1(g) of the Model Oversight Law additionally requires the Authorities Oversight Office to make recommendations to the state's governor (and, as appropriate, the legislature) on setting state SPE debt limitations. To avoid the problem of these limits becoming obsolete over time, as has occurred at the state level with constitutional restrictions on bond debt, ${ }^{152}$ section II.1(g) also requires the Authorities Oversight Office to update its recommendations over time.

The extent to which state SPE debt should be limited will depend on various factors, including the extent to which such debt-and the extent to which state backstopping of such debt-can be transparently disclosed. The less transparent the disclosure, the more such debt should be limited. This suggests a potential conflict of interest: a state that is intent on nontransparently backstopping its SPE debt might not want to follow recommendations of the Authorities Oversight Office. In

152. See generally supra notes 26-28, 38-40 and accompanying text (discussing those constitutional restrictions). 
the event of such a conflict, the only recourse of the Authorities Oversight Office may be to go public with its recommendations-an event that would require significant political will.

\section{Improving State SPE Governance}

The Model Oversight Law adopts several approaches to improving state SPE governance. These approaches seek to strengthen the accountability of state SPEs to state government and, by extension, to the public, while also providing mechanisms for enforcement similar to those provided to corporate shareholders by Sarbanes-Oxley and to bondholders through corporate bond covenants.

On a general level, section III.2(a) of the Model Oversight Law requires each state SPE to inform the Authorities Oversight Office of its governance structure. Subsections (c), (d), and (f) of section II.1 of that Law also require that Office to review and analyze the operations, practices, and reports of state SPEs, to assist state SPEs in improving their management practices, and to recommend to the state's governor (and, as appropriate, the legislature) how to improve state SPE performance. Subsections (c) and (d) of section III.2 require each state SPE to submit to the Authorities Oversight Office a multi-year financial plan as well as a mission statement setting forth the SPE's purposes and goals, a description of its stakeholders (and the SPE's understanding of their expectations), and a selfevaluation.

Section III.1(f) of the Model Oversight Law additionally requires each state SPE to self-examine its governance by establishing a semi-independent governance committee. This governance committee has the duty to review corporate governance trends, to keep the state SPE's management informed of current best governance practices, to review and recommend any necessary or appropriate updates to the SPE's governance, and to advise on the qualifications of the SPE's management.

The Model Oversight Law further attempts to limit conflicts of interest between state SPEs and their managers. To this end, section III.2(a) of that Law requires each state SPE to inform the Authorities Oversight Office of its conflict-ofinterest rules. Section III.1(f) of that Law also enables the governance committee to examine and advise on conflict-of-interest issues. Additionally, section III.2(b) requires each state SPE to report to the Authorities Oversight Office the compensation and other benefits of each member of management whose com- 
bined compensation and benefits exceeds a threshold level. High compensation levels may well signal the potential for conflict. ${ }^{153}$

Finally, section II.2 of the Model Oversight Law imposes penalties on state SPEs and their managers that fail to comply with that Law's requirements. The Authorities Oversight Office has the power to publicly warn and censure state SPEs for noncompliance and to investigate complaints and issue any needed subpoenas. It also may request the state's governor (and, as appropriate, the legislature) to suspend or dismiss members of state SPE management for cause.

\section{CONCLUSION}

Like corporate special-purpose entities, or SPEs, which dominate the so-called "shadow banking" system, ${ }^{154}$ states increasingly are using SPEs to create a vast shadow-financing network invisible to the public. ${ }^{155}$ The result is to reduce the transparency of public finance and to enable government officials to avoid public scrutiny.

For example, because state SPE debt is not technically a legal obligation of the state, states do not have to disclose that debt in their financial statements. ${ }^{156}$ This lack of disclosure can nonetheless be misleading; states often have compelling economic and reputational motivations to, and almost always do, stand behind that debt.

The resulting lack of transparency undermines the ability of the public to monitor state fiscal obligations, thereby misleading investors and citizens as to the state's real costs and increasing the risk of systemic financial contagion. Ominously, the growing political pressure for debt reduction at the federal government level ${ }^{157}$ is likely to exacerbate these effects by push-

153. See supra note 137 and accompanying text.

154. See generally Zoltan POZSAR ET AL., FRBNY StAFF REPORT No. 458: SHADOW BANKING 4-5 (2010) (examining the economics of shadow banking); Steven L. Schwarcz, Regulating Shadow Banking, Inaugural Address at the Boston University Review of Banking \& Financial Law Inaugural Symposium (Feb. 24, 2012), available at http://ssrn.com/abstract=1993185 (defining the shadow banking system).

155. Cf. AXELROD, supra note 75, at 13-15 (characterizing state SPEs as a form of "shadow" government).

156. See supra notes 44-46 and accompanying text.

157. See, e.g., THE NAT'L COMM'N OF FISCAL RESPONSIBILITY \& REFORM, The Moment OF TRUTH 6-7 (2010); Michael Sekora, How to Reduce the National Debt Without Raising Taxes or Cutting Spending, ECONOMY IN CRISIS 
ing even more of a financing burden onto states, in turn increasing their incentives to issue debt through SPEs.

The impact of this lack of transparency on public finance may well turn out to be worse than the impact of corporate SPE lack of transparency on corporate finance. Because states, unlike corporations, cannot fail in the sense of being forced to liquidate, they lack that deterrent against non-transparent use of SPEs. State public finance is also more susceptible than corporate finance to monitoring failures. Creditor monitoring of states and corporations is limited; shareholder monitoring helps fill that shortfall for corporations, but resident monitoring is unlikely to fill that shortfall for states. Moreover, being an integral part of government, state SPEs that lack transparency can undermine not only the integrity of public finance but also constitutional and democratic legitimacy.

A regulatory framework to govern the use of state SPEs is thus critically needed. This Article shows that any such framework should embrace at least four overarching organizing principles: improving transparency of state SPE debt, improving monitoring of state SPE debt, limiting state SPE debt, and improving state SPE governance. Using these principles, the Article proposes a Model Public Authorities Oversight Law and examines how it should apply to state SPEs and public finance, thereby enabling states to utilize the financing benefits of SPEs while controlling their hazards.

(Jan. 22, 2011), http://economyincrisis.org/content/how-reduce-national-debtwithout-raising-taxes-or-cutting-spending; Stabilize the Debt, THE COMMITTEE FOR RESPONSIBLE FED. BUDGET, http://crfb.org/stabilizethedebt/ (last visited Oct. 27, 2012). 


\section{APPENDIX I}

\section{MODEL PUBLIC AUTHORITIES OVERSIGHT LAW ${ }^{158}$}

\section{AUTHORITIES OVERSIGHT OFFICE}

1. The Authorities Oversight Office is hereby established as an independent entity within the [Department of State]. ${ }^{159}$

2. The Authorities Oversight Office shall perform the duties and exercise the powers set forth in this Public Authorities Oversight Law [hereinafter, Oversight Law].

3. The Authorities Oversight Office shall be governed by a Director, appointed by the Governor upon the advice and consent of the [Legislature]. The Director shall hold office for a term of [ _ _ ] years, subject to removal for cause by the Governor [upon the advice and consent of the Legislature]. The Director's compensation shall be established by the Governor.

4. The Director may appoint such officers, employees, and other agents and fix their compensation as the Director deems appropriate [subject to applicable civil service and other appropriate constraints, including State funding limitations and advice and consent of the Governor].

\section{Duties AND Powers OF the Authorities Oversight OF-} FICE

1. The Authorities Oversight Office shall have the duty to

(a) develop a definition of State public authorities that are subject to this Oversight Law [hereinafter Authorities];

(b) develop and maintain a comprehensive list of Authorities and their functions;

(c) conduct reviews and analyses of the operations, practices, and reports of Authorities; tices;

(d) assist Authorities in improving their management prac-

158. This Model Public Authorities Oversight Law, which is based in part on portions of New York State's Public Authorities Reform Act of 2009, 2009 N.Y. Laws ch. 506 is intended solely as a skeletal framework of regulation that could address the article's four overarching organizing principles-improving transparency, improving monitoring, limiting debt, and improving governance. Like the article, the Model Oversight Law is focused on state SPEs. In principle, however, it could also be applied to SPEs established by municipalities or other non-state government units.

159. The Model Public Authorities Oversight Law does not purport to address how the Authorities Oversight Office would be funded. 
(e) assist Authorities in improving the procedures by which their activities and finances are publicly disclosed, including standardizing the content and format of their annual reports and standardizing disclosure of their liabilities;

(f) make recommendations to the Governor [and the Legislature] about improving the performance, reporting, organization, and oversight of Authorities;

(g) make recommendations to the Governor [and the Legislature] on setting debt limitations for Authorities and on updating these limitations as appropriate;

(h) monitor all defaults and all events [hereinafter incipient defaults] that with notice or lapse of time or both would become defaults on debt issued by Authorities, and follow through to understand how such defaults and incipient defaults are resolved;

(i) no later than [date] and annually thereafter, issue reports on its findings and analyses to the Governor [and the Legislature] and, promptly thereafter (except to the extent of any information or analysis therein that is proprietary), make such reports and analyses publicly available; and

(j) provide such other information and analyses as may be reasonably requested by the Governor [or the Legislature].

2. The Authorities Oversight Office shall have the power to

(a) request and receive from any Authority such information, books, records, financial statements, other documentation, and assistance as may be necessary or appropriate to perform the Authorities Oversight Office's duties;

(b) request and receive from the State or any State agency or entity such information, documentation, and assistance as may be necessary or appropriate to ascertain the existence and nature of any direct or indirect guarantees of, or other assurances of payment on, debt issued by Authorities, to the extent such guarantees or other assurances are directly or indirectly backed by the full faith and credit of the State;

(c) enter into cooperative agreements with other government offices to efficiently carry out its work and not duplicate resources;

(d) investigate and act upon complaints or recommendations regarding any Authority, and issue subpoenas pertaining to such investigations;

(e) establish and publish guidelines, and have the power based on such published guidelines, to publicly warn and censure Authorities for non-compliance with this Oversight Law; 
(f) request the Governor [and, as needed, the Legislature] to suspend or dismiss members of management of Authorities for cause;

(g) promulgate regulations to effectuate the purposes of this Oversight Law; and

(h) do anything else necessary or appropriate to effectuate any of the foregoing.

\section{DUTIES OF AUTHORITIES}

1. Each Authority shall have the duty to

(a) cooperate with the Authorities Oversight Office as contemplated by this Oversight Law, including (without limiting the other obligations listed below) providing such information, books, records, other documentation, and assistance as requested in accordance therewith;

(b) maintain audited financial statements, certified by independent public accountants as complying with generally accepted government accounting principles, and deliver copies of such audited financial statements to the Authorities Oversight Office;

(c) inform the Authorities Oversight Office of all outstanding debt securities, including (i) the ratings by credit rating agencies on such debt securities and, promptly after it occurs, any change in such ratings, and (ii) any direct or indirect guarantees of, or other assurances of payment on, such debt securities, to the extent such guarantees or other assurances are directly or indirectly backed by the full faith and credit of the State;

(d) inform the Authorities Oversight Office of all defaults and incipient defaults on its debt and of how such defaults and incipient defaults are resolved;

(e) establish an audit committee, with at least [ [] independent members [who shall constitute a majority of the audit committee, and] who shall possess the necessary skills to understand the duties and functions of the audit committee; the audit committee shall recommend to the Authority's management the hiring of an independent public accounting firm, shall set the compensation to be paid to such firm, and shall provide direct oversight of the performance of the audits performed by such firm;

(f) establish a governance committee, with at least [ independent members [who shall constitute a majority of the governance committee, and] who shall possess the necessary 
skills to understand the duties and functions of the governance committee; the governance committee shall keep the Authority's management informed of current best governance practices, shall review corporate governance trends, shall review and recommend any necessary or appropriate updates to the Authority's governance, shall advise on the skills and experiences required of members of the Authority's management, and shall examine and advise on ethics and conflict-of-interest issues; and

(g) if and when the Authority issues debt or has debt outstanding, establish a finance committee, with at least [ [] independent members [who shall constitute a majority of the finance committee, and] who shall possess the necessary skills to understand the duties and functions of the finance committee; the finance committee shall review and make recommendations on proposals for the issuance of debt by the Authority.

2. No later than [date] and annually thereafter, each Authority shall also have the duty to provide to the Authorities Oversight Office

(a) a description of the Authority, its activities undertaken during the past year, its governance structure, its code of ethics, its conflict-of-interest rules, and (from time to time promptly after it occurs) any change to any of the foregoing;

(b) a listing of the compensation and other benefits, direct and indirect, of each officer, director, other member of management, employee, and agent of the Authority making compensation and benefits aggregating in excess of $\$\left[\_\right]$

(c) a mission statement setting forth the purposes and goals of the Authority, a description of the Authority's stakeholders and the Authority's understanding of their expectations, a set of criteria by which performance of the Authority and achievement of its goals may be evaluated, and a selfevaluation based on those criteria; and

(d) a [ ] -year financial plan, including a current and projected capital budget and an operating budget report.

3. Notwithstanding sections III.1 and III.2 above, the Authorities Oversight Office may, upon application of any Authority, waive any requirement listed in those sections upon a showing that the Authority meets the criteria for such a waiver. Such criteria shall be established by regulations issued by the Authorities Oversight Office with the advice and consent of the Governor [and the Legislature], taking into account (among other factors) the relevance of the requirement to evaluation of 
the Authority's effective operation and the burden such requirement places on the Authority. Each waiver so granted shall be disclosed in the applicable report of the Authorities Oversight Office issued pursuant to section II.1(i) of this Oversight Law. 